\title{
A gender approach to housing loss in Spain: the case of Las Palmas de Gran Canaria
}

\author{
JOSEFINA DOMÍNGUEZ-MUJICA, JUAN PARREÑO-CASTELLANO
}

University of Las Palmas de Gran Canaria, Spain; e-mail: josefina.dominguezmujica@ulpgc.es, juan.parreno@ulpgc.es

ABSTRACT In pre-pandemic times, Spain was one of the European countries where the economic crisis hit the real estate market hardest, leading to rising mortgage foreclosures and eviction of tenants, as highlighted by many scholars on the financial geography of housing. Its matched social effects reveal the outstanding role of gender, foreign status, and income levels, starting from the hypothesis that the intersection among these categories shows the dimension of inequality in the neoliberal configuration of cities. The aim of this article is to provide this evidence through the study case of Las Palmas de Gran Canaria, using a GIS to implement statistical correlations of these categories on a microurban scale. The created database rests on information contained in judicial archives (women's foreclosures and evictions) and on ethnicity and income level statistical information. This allows us to go deeper into the factors of exposure to vulnerability, in accordance with an established academic tradition regarding gender, housing and the city.

KEY WORDS gender - foreclosures - evictions - real estate crisis - income level - foreign status

DOMíngueZ-MUjiCA, J., PARREÑo-CASTELlANo, J. (2021): A gender approach to housing loss in Spain: the case of Las Palmas de Gran Canaria. Geografie, 126, 2, 123-147.

https://doi.org/10.37040/geografie2021126020123

Received September 2020, accepted May 2021.

(C) Česká geografická společnost, z. s., 2021 


\section{Introduction}

Periodic economic crises are inherent to the logic of the capitalist system, since the basic tendency to over-accumulation generates surpluses of capital, scarcity of investment opportunities, falling rates of profit, and a lack of effective demand (Domínguez-Mujica, 2021). The bursting of the financial bubble in 2007-2008 and the bankruptcy of the real estate market, based on excessive indebtedness of households, the last great crisis linked to over-accumulation, brought about those consequences.

In Spain, this bubble was preceded by intense economic growth at the turn of the century, a period intrinsically associated with real estate development due to its strategic character in the economic policy. The business expectations of landowners, developers and builders required expansion of the effective housing demand, which was carried out through measures implemented by financial institutions, real estate agents and the political-administrative system. In this context, given that most citizens had limited purchasing power, it was necessary to offer conditions in the mortgage credit market that could be assumed by most potential buyers.

The widespread perception that housing was a solid investment that would always provide profitability encouraged potential buyers to acquire loan mortgages. "Investment in housing was portrayed as the best savings option for ordinary citizens who did not have capital or lacked the skills to invest in the financial market" (Casellas, Sala 2017, p. 168). Additionally, in Spain, real estate ownership has been part of the Spanish social idea of progress since the 1950s, when it was promoted as the most desirable tenure choice. As indicated by Di Feliciantonio and Aalbers (2018, p. 146), "the fascist-dictatorial regimes of Mussolini and Franco saw the construction sector and the promotion of homeownership as keys to fuel the accumulation process while believing this guaranteed social order". Therefore, the Spanish ownership ideal was deeply rooted in turn of the century neoliberalism, when the number of homes sold grew markedly and a new subprime middle class emerged (Suárez 2017).

However, the economic crisis showed the weakness of this real estate model based on excessive indebtedness. When in 2008 worsening of the labour market reduced disposable income, new middle-class owners began to have difficulties paying their mortgage loans. In addition, house price depreciation made it impossible to recover real estate investments by selling. Consequently, an increase in foreclosures $(630,896$ foreclosures were initiated, and 430,403 evictions ordered between 2008 and 2015 - Banco de España, 2015) and tightening of the requirements for mortgage loans grew the demand for rental accommodation. Many tenants had serious difficulties making rent payments, leading to more evections. That is, evictions for non-payment of mortgages and rent arrears became two 
sides of the same coin of the real estate crisis, affecting low and middle income social classes and, especially, unemployed, precarious workers and single-parent families.

Furthermore, a detailed analysis of these foreclosures and evictions reveals that they have differentiated effects because of their relationship to ethnicity, as well as income (Raya 2018) and gender (Vázquez-Vera et al. 2016), as interdependent explanatory categories of the real estate and housing crisis. In this paper we try to document them through the case study of Las Palmas de Gran Canaria, the largest city in the Canary Islands (Spain), whose metropolitan area has a population of over half a million.

We propose to approach the real estate crisis in Las Palmas de Gran Canaria by analysing the spatial relationships that loss of housing has with income levels, foreign status and gender, since they are social and spatial categories, allowing for the interpretation of social inequalities and geographical disparities. We believe, on the one hand, that the city of Las Palmas de Gran Canaria is an example of the incidence of the explanatory categories of gender, income and ethnicity on the pattern of mortgage foreclosures and evictions after the $2008 \mathrm{crash}$ and, on the other, that these three categories are strongly linked. This case study is relevant in light of the research on social and economic factors related to housing in financialized urban capitalism.

This general goal guides the specific objectives of this paper: to quantify the foreclosures and evictions from non-payment of mortgages or rent according to gender; to interpret their evolution during the financial crisis; to map the territorial distribution of dispossession of women in the city; to analyse the spatial relationship of disposable income and the condition of being a foreigner as underlying loss factors for women's homes; and, finally, to establish a micro-urban scaled geography of the city according to these categories in order to deepen the knowledge of housing loss among women. The text is structured in the following manner. After this introduction, in the second section, a conceptual outline is elaborated. In section three the sources and methodology of this study are set out. The results of the research are shown in section four, including the magnitude of the process of mortgage foreclosure and evictions affecting women, the evolution in time and the relationship between gender, income level and foreign status. The paper concludes with a reflection on housing loss from a gender perspective due to the value of this clarifying element for the study of the real estate crisis and its spatial and socially unbalanced effects. 


\section{The framework of the study}

\subsection{The real estate crisis in a European country}

The US real estate crisis that resulted in a global credit crunch affected real estate markets in different countries and, consequently, the financial geographies of housing received an enormous boost. Aalbers (2019) examined the most recent research on finance, real estate and housing, highlighting a set of studies devoted to household indebtedness and rising mortgage debt, and to the financialization of rental housing and the eviction of tenants in different countries of the world. These issues have been deeply investigated in Europe, despite European markets being quite different from one another because of cultural, tax and juridical differences. Spain has been hit the hardest together with the United States (Beswick et al. 2016) and, previously, was the European country whose economic growth rested on real estate development and on the housing market subsector in a greater proportion. For this reason, the case of Spain demands singular attention.

Research carried out by Etxezarreta Etxarri et al. (2012) shows the impact of the crisis was related to the intensity of real estate growth that occurred in Spain between the turn of the century and 2008, but the predominant theoretical approach was that of interpreting the real estate crisis in Spain in the context of the financialization of the global economy and the process of over-accumulation. Accordingly, some scholars placed emphasis on the explanatory framework of the theory of capital circuits (Gutiérrez, Vives-Miró 2018; Méndez 2017; ParreñoCastellano et al. 2019) while others revealed the surreptitious actions of the financial "alchemy" of the Spanish housing market (Alexandri, Janoschka 2018).

Complementary to this theoretical discourse, at least three lines of argument have been developed. First, some researchers have related loss of housing to the unbalanced tenure structure and the mismatch between supply and demand. The clear growth of home ownership from 77.8\% in 1990 to $85 \%$ in 2011 (Andrews, Caldea Sánches 2011), through subprime mortgage loans, led to a continuous mismatch between prices and income. In relation to the rental market, the approval of the legal corpus for the promotion of the rental housing market (Act 4/2013, of 4th June) and the changes carried out in Civil Laws have been interpreted as tools that have facilitated loss of housing since these legal changes allowed shorter contracts and more agile eviction processes.

Secondly, the rapid process of internationalisation in the Spanish housing market since 2013 has been considered a relevant factor to understand the situation in the last years. Propitiated by governmental policy, emerging international investors had acquired a great number of real estate properties, which influenced an increase in rental prices (Janoschka et al. 2019). This internationalization of home ownership through a policy that ensured a profit for large international 
investors, powerful economic agents, and financial institutions is the necessary requirement for understanding that it went from a model of accumulation to one of accumulation by dispossession and subsequent repossession (DomínguezMujica 2021).

The third approach to explain the complexity of the real estate crisis in Spain is that of the recent increase in the number of vacation rental properties in many cities, especially in coastal areas. The development of this type of rental housing has caused a speculative bubble in the prices and, consistently, many housing units have been withdrawn from the residential market to be devoted to tourist use. In recent years, the new system of online booking has triggered an unprecedented process of tourism gentrification in certain neighbourhoods, which has favoured the number of evictions (Domínguez-Mujica, Parreño-Castellano, Moreno-Medina 2020). These processes can be recognized in the case study concerned and in other Spanish cities on the Mediterranean coast and in the Balearic Islands (DomínguezMujica et al. 2021).

Finally, a detailed analysis of these processes requires a microscale approach, as has recently happened in Spain, where different scholars have interpreted the social effects of housing loss through micro-urban studies, focusing on the most affected areas of the Spanish Mediterranean and Insular municipalities. These studies show socio-spatial differences that dispossession and eviction for non-payment of rent seem to demonstrate. In this regard, the micro-urban analysis carried out for the Balearic Islands by Vives-Miró, Rullan, González-Pérez (2018) defends that foreclosures predominated in districts of low status in Palma (Mallorca), while evictions for non-payment of rent have been more numerous in middle-class and upper-class neighbourhoods. For the Canary Islands, GarcíaHernández, Díaz-Rodríguez, García-Herrera (2018) and García-Hernández, Ginés (2020) indicated that the highest rates of eviction for non-payment of rent corresponded to the city centre and the suburban developments in Santa Cruz de Tenerife, in comparison with the greater incidence of foreclosures in the second outskirts of the city. For Catalonia, Gutiérrez, Arauzo-Carod (2018) and Gutiérrez, Domènech (2020) revealed that most of the buildings of the banking sector, after processes of foreclosure, were concentrated in working-class neighbourhoods of different Catalonian cities. These are good examples of the imbalanced impact of the real estate crisis from a microscale perspective.

\subsection{Gender and housing dispossession}

The gender perspective on city and housing has been consolidated by feminist research since the seventies. As stated by Bondi, Rose (2003, p. 232): "over the past two to three decades, feminist scholarship in urban studies has thus indubitably 
established the centrality of gender to analysing cities and urban life". This assertion is based on a greater feeling of attachment to the home and housing by women (Hill 2011), because housing contributes to their independence, economic security and bargaining power (Miraftab (2001). This idea was also defended by Chant (2013, p. 16), who stated that "housing is a key resource for women; it is an asset important to their economic condition and central to their physical and social well-being. It is the site of childbearing and income generation and a nexus for social networks of support and community-based reliance". Given that, in the neoliberal context, the home is redefined as an object of speculation and investment, transforming the spaces of home and household into enterprises (Foucault 2008), women have been more affected than men by housing loss, due to the significance of home and housing to their lives.

To these reflections must be added the fact that access to housing is more difficult for women (Roberts 2013) and women assume a greater risk when taking on debt to acquire a house (Bayer, Ferreira, Ross 2013; Castro Baker 2014; Faber 2018; Ferreira, Gyourko 2015; McCormack, Mazar 2015; Wyly, Ponder 2011). Thus, Lichtenstein, Weber (2015) confirmed that high-risk loans granted to single women during the real estate boom in the American Deep South, implied a higher exposure to foreclosure a few years later. Something similar occurred regarding evictions due to rent arrears, as demonstrated by Desmond in his studies on Milwaukee (Wisconsin-USA; Desmond 2014, 2016) and by Hepburn, Louis, Desmond (2020) on 1,195 US counties.

The mentioned references lead us to investigate the impact of the recent predation of mortgage finance, foreclosures, and evictions on men and women, giving the gender perspective the importance it deserves in the study of dispossession. In current capitalist societies, there is no doubt about the serious consequences of the real estate crisis according to social class division (labour market). However, given the complexity, blurring limits and overlaps of social strata, the most accurate analytical viewpoint is to consider its intersection with the categories of ethnicity and gender, since mortgage segmentation and risk-based pricing work across a hierarchy of ethnic, gendered and class differences (Allon 2014).

Despite the fact that the position of women in society can change in relation to time, class status, and cultural context, social constructs of class, ethnicity and gender have existed throughout history and function concurrently in all circumstances, creating situations of difference (Constantine 2002). Although most approaches set stratification of gender and ethnicity in symbolic or cultural realms, while class is regarded as pertaining to material inequality, the categorical formations of gender and ethnicity are important elements of social stratification. They constitute particularly salient constructions of difference and identity on the one hand, and hierarchization and unequal resource allocation modes on the other (Anthias 2001). 
We adopt the second perspective in this case study, since it allows us to defend the greater vulnerability that women present in situations of real estate dispossession. A considerable number of studies carried out in the United States are situated in this line of empirical research. However, in Europe, the number of published works has been lower, with Ireland (Wöhl 2017) and Spain (Lombardo 2017) as exceptions. The cause of this imbalance is due to the fact that the records that report dispossession procedures do not contain data on whether the persons affected are men or women and because the impact of the real estate crisis through dispossession procedures has been very uneven according to countries, the former being some of the most affected.

In Spain, Bosch Meda (2020) used the data from the European Survey on Income and Living Conditions (EUROSTAT) to reveal how the social crisis affected women and their relationship with housing. From a qualitative analysis, in relation to foreclosures, García-Lamarca (2016) and Suárez (2017) studied the citizens' response to foreclosures based on monitoring the actions of the Platform of those Affected by Mortgages. Suárez concluded that the subprime social class, constituted of precarious workers, had a specific ethnic and gender composition. Some researchers have also analysed the repercussion of home loss for non-payment of rent among women. Amnesty International (2017) implemented interviews with evicted women in Spain to confirm their greater vulnerability. Additionally, Domínguez-Mujica, Parreño-Castellano, J., Armengol-Martín (2020), based on interviews with defence attorneys for women involved in eviction proceedings, highlighted that immigrant women show greater weakness in the rental market. Therefore, these studies have used the category of gender from the point of view of higher feminine economic vulnerability and the weakness that comes when it intersects with foreign-ethnic status and social class. This is the research framework used in this case study.

\subsection{The geographical context: a port and Spanish tourist city}

Las Palmas de Gran Canaria is the largest city in the Canary Islands, an archipelago located on the outermost periphery of the European Union. Its metropolitan area covers a large part of Gran Canaria Island, whose population is close to one million inhabitants. From the point of view of urban specialization, it is a port city with an important tourism activity, favoured by its mild weather, the high number of sunny days and long beaches (Domínguez Mujica et al. 2020). In 2018, the city had a stock of regulated accommodation amounting to 12,502 beds, an increasing volume of registered vacation houses, with more than 9,300 beds, and it received more than half a million visitors arriving by cruise ships. Moreover, a high number of foreigners live in the city, both labour and lifestyle migrants. 
The above-mentioned factors have allowed the development of an active housing market aimed at local and international demand. This has altered availability and prices of housing for the local population, especially during the Spanish real estate boom and the subsequent economic crisis. The latter was particularly hard, with high rates of unemployment, increasing poverty levels and urban inequalities hindering access to housing. But the right to housing has also been undermined after the crisis, as demonstrated by the high number of foreclosures and evictions during the economic recovery, while, paradoxically, vacation houses developed extraordinarily.

Thus, Las Palmas de Gran Canaria shows the most relevant urban processes of the Spanish real estate market, such as internationalization of the housing market; development of vacation rentals; upsurging gentrification; increase in foreign investment for the acquisition of houses; the appearance of new real estate investment companies and so-called vulture funds; growth in the purchase of homes and rental prices; and the rise in foreclosures and evictions. These processes, common to other urban spaces in the Spanish coastal Mediterranean provinces (AlmeidaGarcía, Cortés-Macías, Parzych 2021), as well as outside of Spain (Mendes 2018), make Las Palmas de Gran Canaria a clear example of many of the recent urban trends in Europe.

\section{Research method}

Although research in relation to the social dimension of the real estate crisis in Spain has made use of qualitative processes of analysis (Arredondo, Palma 2013; Sabater, Giró 2015), legal sources have become the most widely used quantitative tools for geographical research. This is because it is the only official register on loss of housing existing in Spain. Nevertheless, this source shows great limitations for the identification of social processes, since no information is supplied on the persons affected by dispossession. This was recognised by Amnesty International, when it indicated that data on evictions reflect their number and spatial distribution but not the type of person affected. "We do not know how many of them are men, women, children, adults, victims of domestic violence, foreigners or from other groups (2017, p. 5)". This limitation is not exclusive to Spain. In the USA, records of eviction, unfortunately, do not include gender (or race) identifiers, as was recognised by Desmond (2012). This constraint was partially solved in the current research by conducting a micro urban study that enables us to know the territorial distribution of loss of housing for women and, later, to relate this distribution to that of other socio-demographic variables. 


\subsection{Data collection}

The information with which we have conducted this research comes from the files registered by the Common Service of Notifications and Seizures (ParreñoCastellano et al. 2018). The Spanish judicial districts of greatest demographic size have the so-called Common Services, a procedural unit, configured in 2003, which centralises the actions of different courts and carries out acts of notification and enforcement. To this purpose, the Common Services uses a system of digital procedural management. The reserved nature of information means that only aggregated data at the judicial district level can be consulted. In our case, with the guarantees required by data protection, we have been able to access records individually, which has allowed us to obtain legal and geographic data from each of the files processed.

A database was constructed wherein each file of foreclosure or eviction for non-payment of rent corresponded to a record. The data included were the postal address, status of judicial implementation, type of judicial diligence (ejectment, transfer of possession, attachment), type of judicial proceeding (civil, criminal, familiar...), type of judicial category of each proceeding (foreclosure, oral hearing...), date (year and quarter), spatial entity (municipality, postal district, neighbourhood and census tract) and gender of the main person affected.

The identification of gender required a qualitative treatment since we only had the first name of the mortgager or tenant (the second name was anonymised for the sake of confidentiality), and assigned the corresponding category from the identification of the name as masculine or feminine. This practice involved a certain risk since it was not a self-declaration, as would be required to define a person as a man or a woman. Nevertheless, we proceeded as Desmond had done (2012), imputing a sex to each person, after a comparison of opinions of the two technical assistants who were responsible for the database. Unanimity was achieved in all proper names in the Spanish language, while there were greater discrepancies regarding names in other languages (a minority of cases), with the result that the reliability and agreement amounted to $95 \%$ of the records. In cases of disagreement, other members of the research team were consulted who decided one way or the other. When the proper name was ambiguous or was not recorded, it was excluded from the database (1.55\%).

We must consider that women are probably underrepresented, since it is a generalised practice in Spain that men are the first to sign title deeds or rental contracts. This practice, inherited from a past when a woman could not make use of her goods without authorisation of her husband, leads to an undetermined percentage of women not appearing as affected. Despite these constraints, a database on feminine eviction was generated, where each of the records corresponds to a judicial file with positive dictum. Based on the postal address of properties 
affected, 1,233 files were georeferenced with a point topology, using a Geographical Information System.

Given that the gender attribute as an explanatory factor seems to be related to social class and race, we extrapolated both categories to the Spanish context and to the statistical availability, choosing income and foreign status as indicators (ParreñoCastellano, Domínguez-Mujica, Moreno-Medina 2020). Therefore, information on the foreign population from the Continuous Population Register was first added to the GIS. The data on the foreign population was introduced for almost 300 census tracts of the city, as these are the spatial units which present the highest level of disaggregation (INE 2020). Second, the disposable income data from the Spanish Tax Agency were added. This tax information comes from the income statements of individuals (Treasury 2019) and is publicly offered for the 20 municipal postal districts. Consequently, this geographical scale was also introduced in the GIS.

Using postal address and the vector analysis tool that makes it possible to associate point and polygon topologies, we obtained the census tract and postal district codes for each eviction record. This allowed us to interrelate the three spatial scales mentioned and resulting information on the number of foreigners and evictions and average disposable income for each postal district.

\subsection{Statistical and spatial analysis}

The geographic database of evictions was statistically and spatially analysed to know the territorial distribution of the files in the urban space. Given the lack of demographic and economic data in the judicial records, we used the analysis of the distribution of actions and their relationship with the income and foreign status by postal district. This allowed us to characterize the affected women and, consequently, to interpret the category of gender as an explanatory variable. Specifically, an analysis of bivariate correlation was made between the territorial distribution of women's housing loss records and the average disposable income at the postal district level, and also between the territorial distribution of women's housing loss records and the number of foreigners.

The judicial actions and number of foreigners are characterised by a frequency distribution tending to normality, but asymmetrical at the level of the census tract. The spatial concentration of both variables in certain sections determined that both presented 21 outliers. This lack of normality meant that the analyses of parametric association might have a clear bias. Consequently, it was decided to carry out analysis at the level of the postal district since the aggregation of data normalised the distribution. In the case of the foreign population, it was also necessary to transform the data by means of a Natural logarithm. As a result, both variables fulfilled the condition of normality, according to the Shapiro-Wilk test. 
The calculation of correlations was completed with that of linear regression in order to determine their predictive character. In both cases, the functions of regression were significant. Furthermore, with the purpose of evaluating the adjustment of the functions, autocorrelation of data was checked. The DurbinWatson test values offered a lack of positive autocorrelation in both variables and inconclusive values for negative autocorrelation only in the case of income. ANOVA (F) analysis of both models was also significant $(\alpha=0.01)$, supporting the robustness of both linear regressions.

The study was completed with a model of multiple association-regression in which we combined the two factors analysed at the district level (income and foreign status) with the spatial distribution of the files of loss of housing. We previously evaluated the interdependence of predictive variables by means of the calculation of partial correlations. This made it possible to obtain significant associations that allowed us to rule out common underlying causes ( $12.3=-0.68$ for income and r13.2 $=0.81$ for the foreign population). As in the bivariate regressions, autocorrelation was not observed, with a significance of 0.05 , and multi-collinearity was not recognised between the two predictive factors, with a tolerance close to unity in both cases.

The results obtained allowed us to delimit urban areas according to the territorial distribution of legal actions registered against women and those of both predictive factors. This intra-urban analysis was made through a hierarchical cluster using data aggregated by postal district. The measure of relation used in the multivariate cluster was the squared Euclidean distance to obtain homogenous groups that would be easy to interpret, and the method employed was the average linkage between groups. As a result, five homogeneous groups were obtained, which allowed us to distinguish the different spatial incidence of the loss of housing of women inside the city.

\section{Results}

\subsection{Real estate dispossession from a gender perspective}

Higher feminine vulnerability, together with income level and ethnicity, can be demonstrated through empirical research on the pattern of mortgage foreclosures and evictions in the city of Las Palmas de Gran Canaria, where 4,061 forcible deprivations of use and ownership judicial actions were implemented between 2009 and 2017. Of 3,202 corresponding to private individuals whose gender we knew, $38 \%$ were women. Those caused by mortgage non-payment amounted to $56.5 \%$, with the remaining $43.5 \%$ being cases of eviction due to non-payment of rent. 


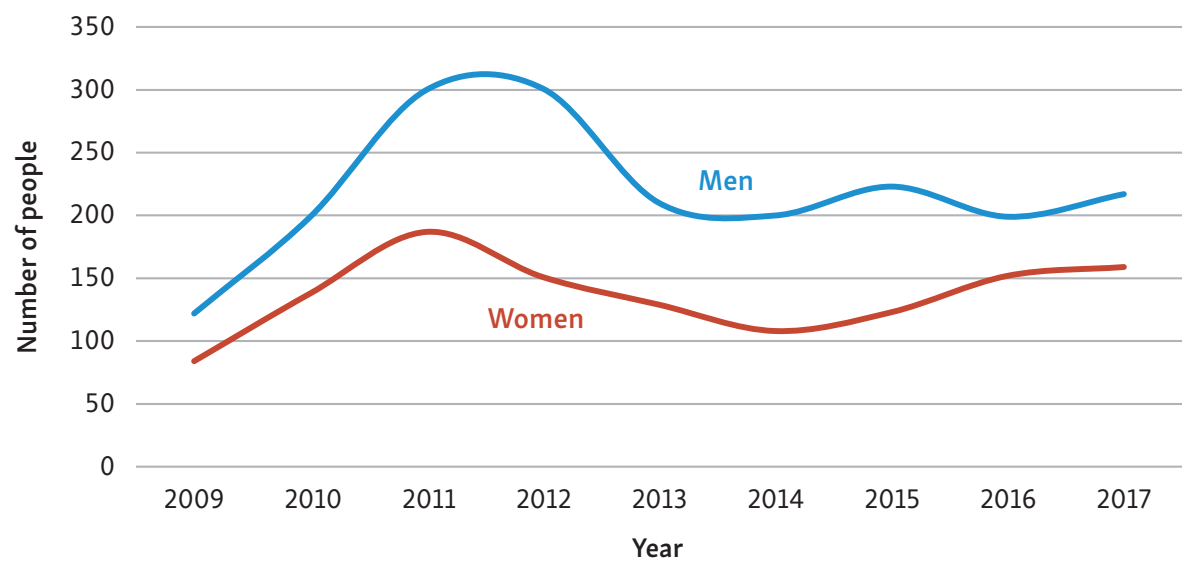

Fig. 1 - Evolution of the loss of housing according to gender. Source: Common Service of Notifications and Seizures. Elaborated by authors.

Time evolution in the analysed period is shown in Figure 1. The data depict a significant increase in legal actions between 2010 and 2011; delayed judicial procedures of the real estate crisis (2008-2010) coinciding with the so-called debt crisis (2011), when the governmental measures of budget austerity and public deficit control gave rise to a devaluation of salaries and high unemployment. Since 2013 , there was a reduction consequent with the approval of Act $1 / 2013$, of 14 th May, on measures to reinforce the protection for mortgage debtors, restructuring of debt and social rented housing. From 2016 onwards, the figure again showed a tendency to a slight growth, a phenomenon linked to the evictions for nonpayment of rent arrears. Therefore, although this figure depicts the relationship between the economic situation, changes in laws and dispossession, it also reveals its structural character since, even in periods of economic recovery, loss of housing has been recorded.

When the evolution of judicial proceedings is analysed from the point of view of gender, several nuances must be appreciated. First, lower figures of housing deprivation for women might make us think that these are less affected, but the records on the men/women as housing owners point out that, before the 2008 crisis, the number of Spanish households whose reference person was a man was higher than that of a woman, 10,129,400 vs 5,986,900 (INE 2007).

Second, the percentage of files against women is related to feminine bias of some types of household. $83 \%$ of single-parent households and $54 \%$ of one-person households are made up of women, according to the Continuous Household Survey (INE 2017). A good part of actions directed against women affects these households, especially single-parent ones as pointed out by Amnesty International Spain (2017). Additionally, after examining the complaints received by the Andalusian 
Ombudsman, Sánchez (2015) detected a notable increase in evictions, either due to non-payment of mortgage or rent, among households headed by a woman with family dependents.

Third, time analysis for the loss of housing allows us to observe that, in the periods of crisis (2009-2011 and 2014-2015), the cases of masculine deprivation are more numerous in comparative terms. However, with the economic recovery (2016-2017), the figures of dispossession for men and women seem to be similar. Consequently, loss of housing on the part of women shows a more homogeneous evolution, denoting a greater vulnerability to structural factors. In this sense, job insecurity and salary gap between men and women or greater feminine family commitments are persistent factors both in crisis and recovery periods.

\subsection{Factors of eviction: level of income and foreign status}

Given that in existing literature, income level and ethnicity have been highlighted as the two elements that best define the risk of loss of housing for women, we have considered average disposable income and the condition of foreigner as spatial indicators of vulnerability.

From a territorial point of view, foreclosures and evictions against individuals are present in all postal districts of the city, although to a differing extent. The average of judicial actions by district was 159.6 with a standard deviation of 103.1, which shows a high variability in the distribution of the number of procedures by postal district.

If we look at the type of judicial proceeding, notable differences can be appreciated. Evictions are greater in the port and tourism areas and surroundings, a central area which has been affected by processes of tourism gentrification, while foreclosures stand out, apart from this area, in suburban districts (Fig. 2).

This territorial distribution is partially explained by the unequal distribution of income in Las Palmas de Gran Canaria. The correlation between both spatial variables is moderate and negative $(r=-0.57)$ with a level of bilateral significance of 0.05 . This association is higher for women than men. This means that, in general, as socio-economic status rises, the number of legal proceedings becomes less, with a determination coefficient $\left(\mathrm{r}^{2}\right)$ of 0.32 and a model of regression established by the linear function $y=-0.0046 x+170.05$ (Fig. 3).

Consequently, if we classify districts according to the levels of average disposable income into low-income, low-to-medium, medium, and high-income districts (Fig. 4a), and we relate them with the distribution of judicial actions, the ratio of foreclosed and evicted women goes from $3.4 \%$ in those with highest income to $47.5 \%$ in those with low income. The greater correlation between loss of housing and income among women, with respect to that of men, shows their greater vulnerability. 


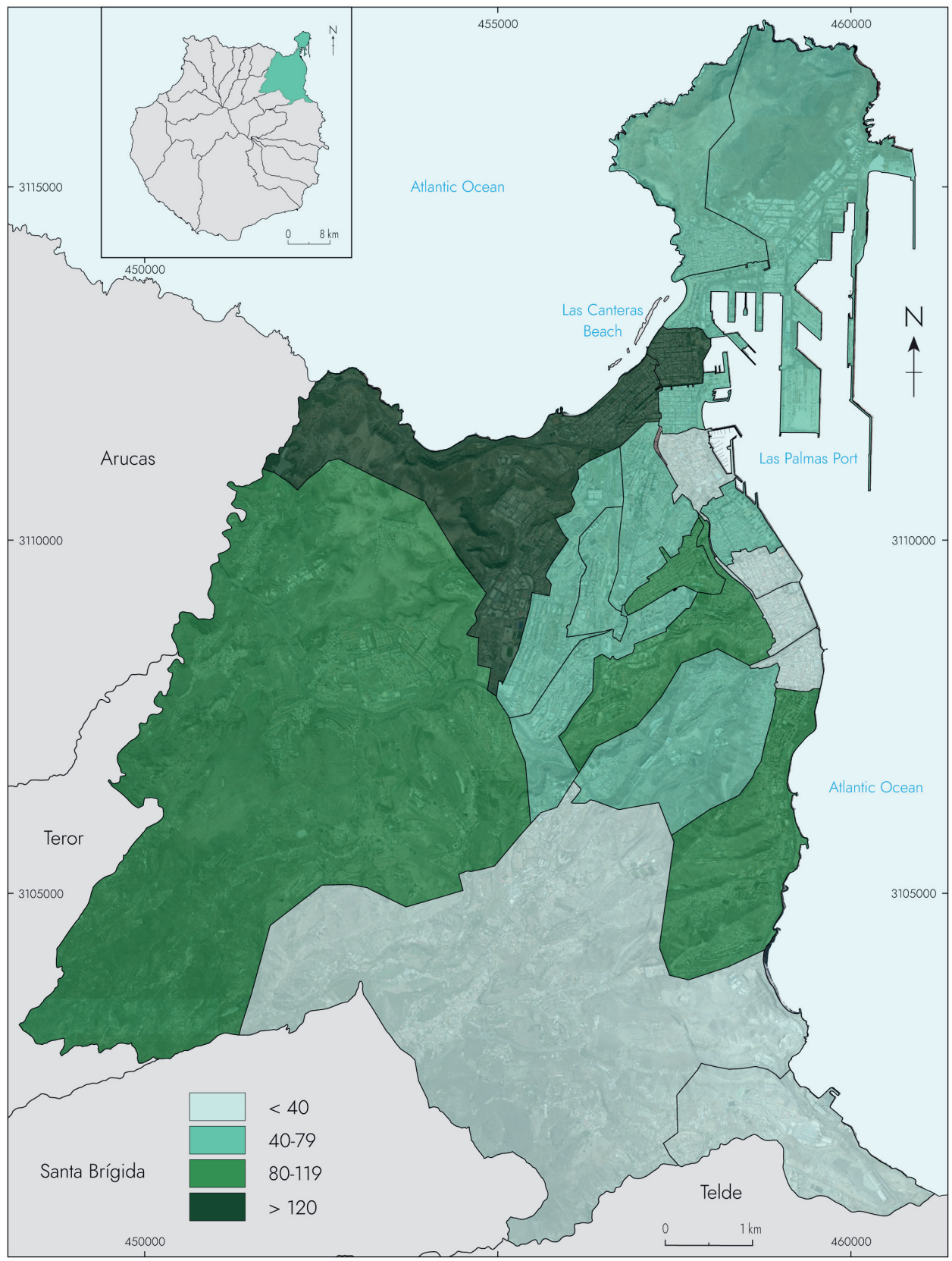

Fig. 2 - Distribution of foreclosures and evictions against women by postal district. Source: Common Service of Notifications and Seizures. Elaborated by authors. 

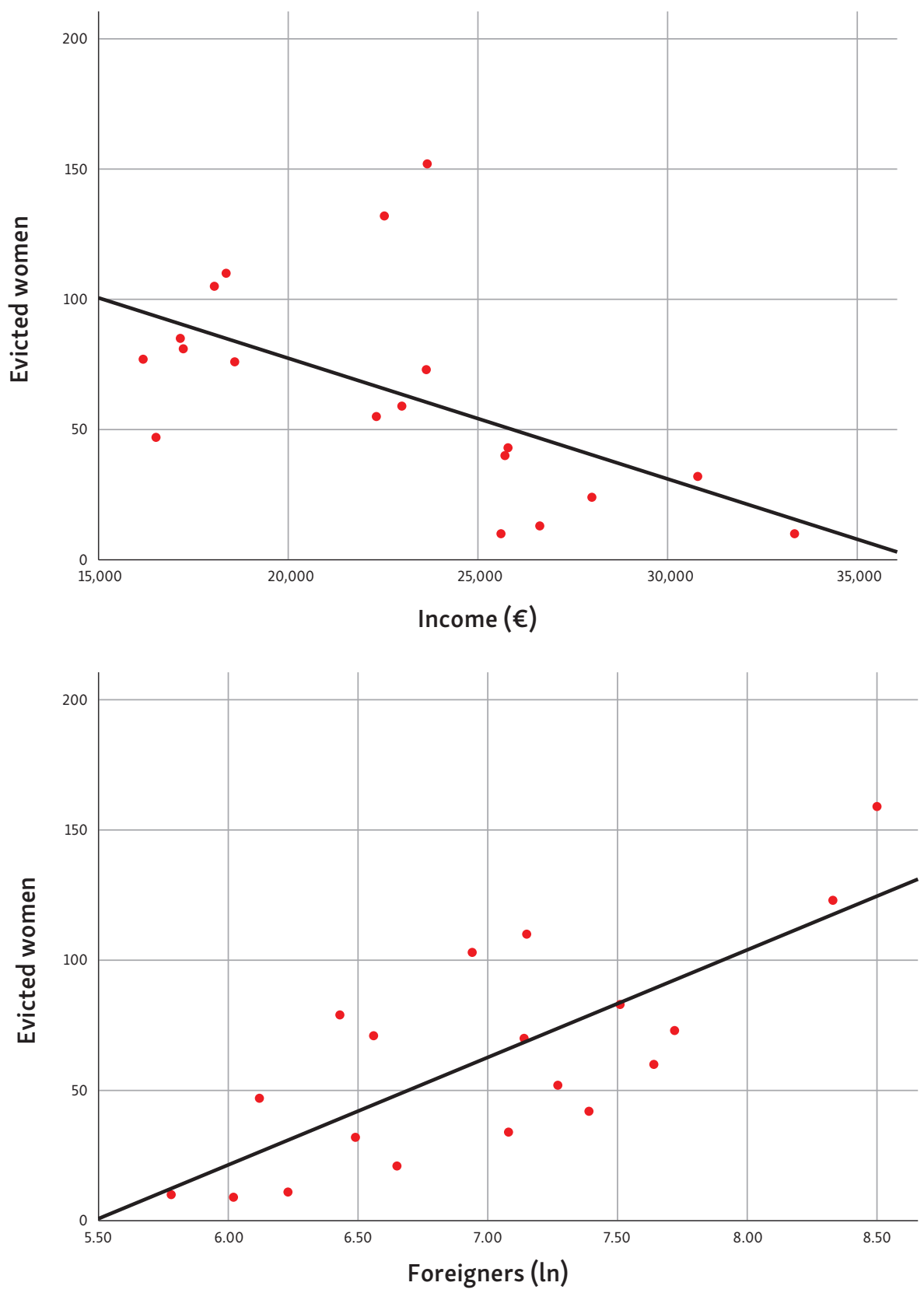

Fig. 3 - Linear Regression between foreclosed and evicted women and income (top) and number of foreigners (bottom). Source: Common Service of Notifications and Seizures, Tax Agency, Statistics from those declaring for Income Tax and Continuous Register of Population (INE). Elaborated by authors. 


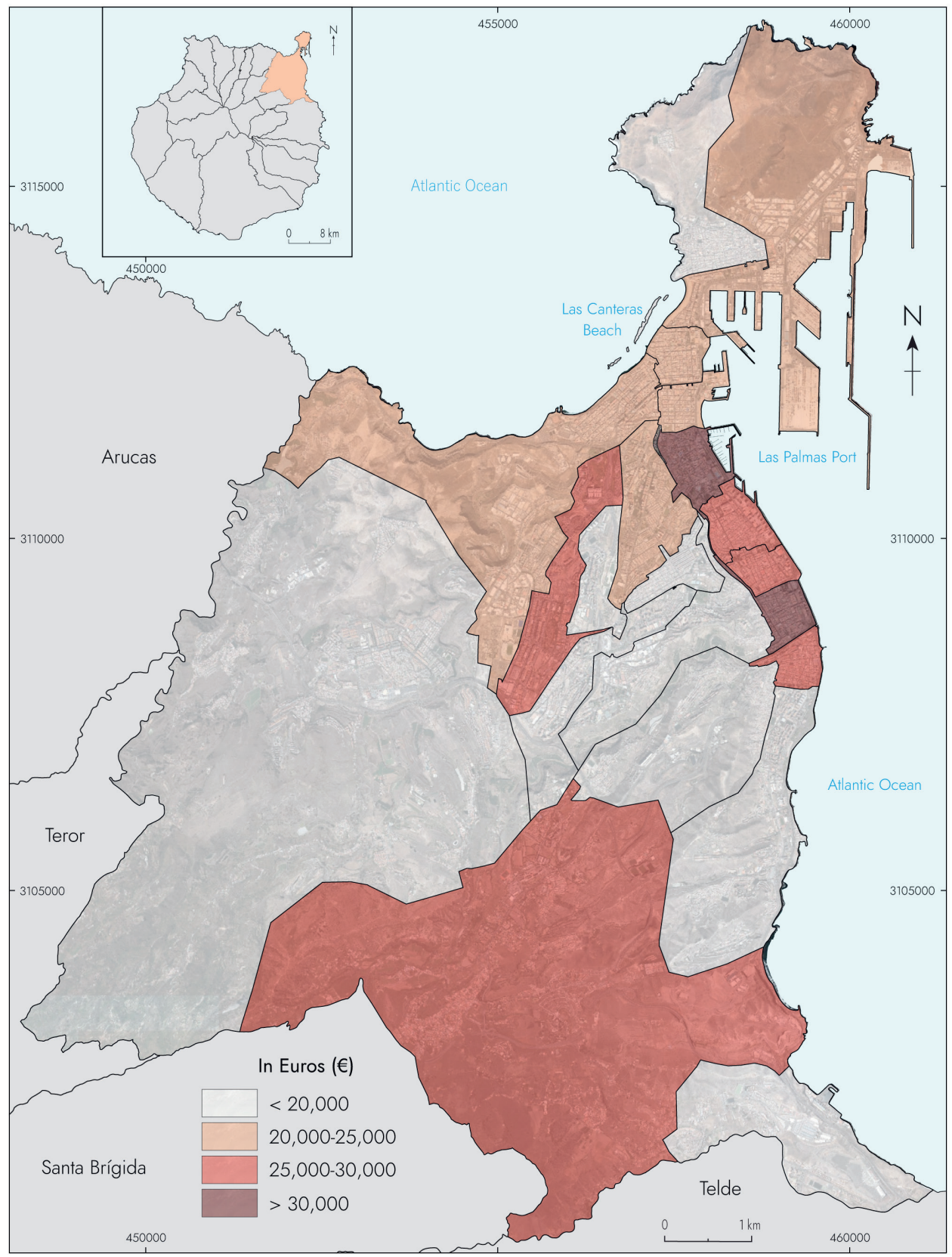

Fig. 4a - Postal districts by average disposable income. Source: Statistics from those declaring for Income Tax and Continuous Register of Population (INE). Elaborated by authors. 


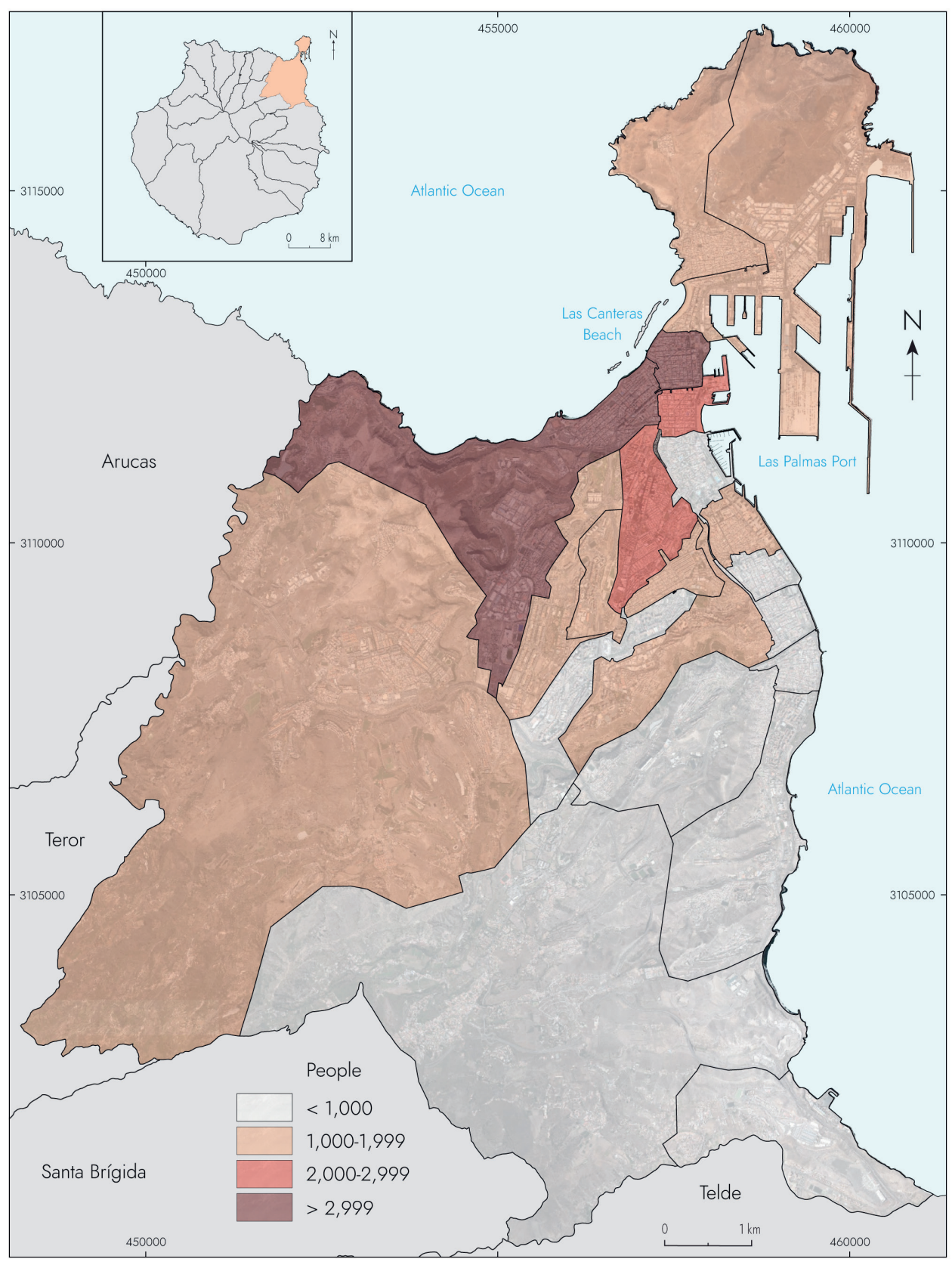

Fig. 4b - Postal districts by number of foreign population. Source: Statistics from those declaring for Income Tax and Continuous Register of Population (INE). Elaborated by authors. 
Table 1 - Statistical Information on Clustering

\begin{tabular}{lcccc}
\hline Groups & $\begin{array}{c}\text { Number of postal } \\
\text { districts }\end{array}$ & $\begin{array}{c}\text { Average Judicial } \\
\text { Actions }\end{array}$ & $\begin{array}{c}\text { Average income } \\
\text { (Euros) }\end{array}$ & $\begin{array}{c}\text { Average number of } \\
\text { Foreigners }\end{array}$ \\
\hline I & 2 & 142 & 23,098 & 4,512 \\
II & 6 & 89 & 17,594 & 1,121 \\
III & 5 & 54 & 24,092 & 1,719 \\
IV & 2 & 26 & 17,433 & 302 \\
V & 5 & 18 & 28,877 & 534 \\
\hline Total & 20 & 61 & 22,574 & 1,381 \\
\hline
\end{tabular}

Source: Common Service of Notifications and Seizures, Tax Agency and Continuous Register of Population (INE). Elaborated by authors.

On the other hand, if we categorize districts according to the proportion of the foreign population residing there (Fig. 4b), it can be observed that in the group of those with the most foreigners, many of the legal proceedings affecting women are concentrated. In the first quartile, made up of districts with the smallest numbers of foreigners, $6.9 \%$ of the legal actions are developed while in the final quartile, the districts with greatest foreign presence, $41.7 \%$ of the cases are against women. Therefore, as the proportion of foreign population in the district grows, the number of legal actions does so too with a high direct and positive correlation of $r=0.76$, with a level of bilateral (two-tailed) significance of 0.01 . The determination coefficient $\left(r^{2}\right)$ is 0.57 and the linear model is expressed by means of the function $y=40.973 x-222.281$ (Fig. 3).

In other words, women show greater vulnerability to loss of housing if they reside in low-income districts with a high proportion of foreign population. This leads us to interpret that these two socioeconomic characteristics are relevant in the group of women affected by housing deprivation.

Finally, the multiple modelling we have carried out, combining the data on wealth (income) and foreign status indicates a very high joint association $(r=0.88)$, with an adjusted determination coefficient $\left(\mathrm{r}^{2}\right)$ of 0.74 . That is, $74 \%$ of the variability of judicial actions which have affected women is explained by the joint influence of both predictive factors. The model of multiple linear regression responds to the function $\mathrm{y}=37.7 \mathrm{x}-0.004 \mathrm{z}-108.862+\mathrm{e}(\mathrm{x}=$ number of foreigners; $\mathrm{z}=$ average disposable income). These data mean that, with only two of the variables often used in studies of urban vulnerability, three quarters of the cases of foreclosures and evictions of women in the city of Las Palmas de Gran Canaria are explained.

Once the relationship between feminine deprivation and these two factors of vulnerability has been confirmed, it is possible to analyse their joint territorial expression. We have used a multi-variable clustering of the three spatial distributions with this purpose, resulting in five homogenous groups (Fig. 5), as can be seen in the basic statistical characteristics of Table 1. 


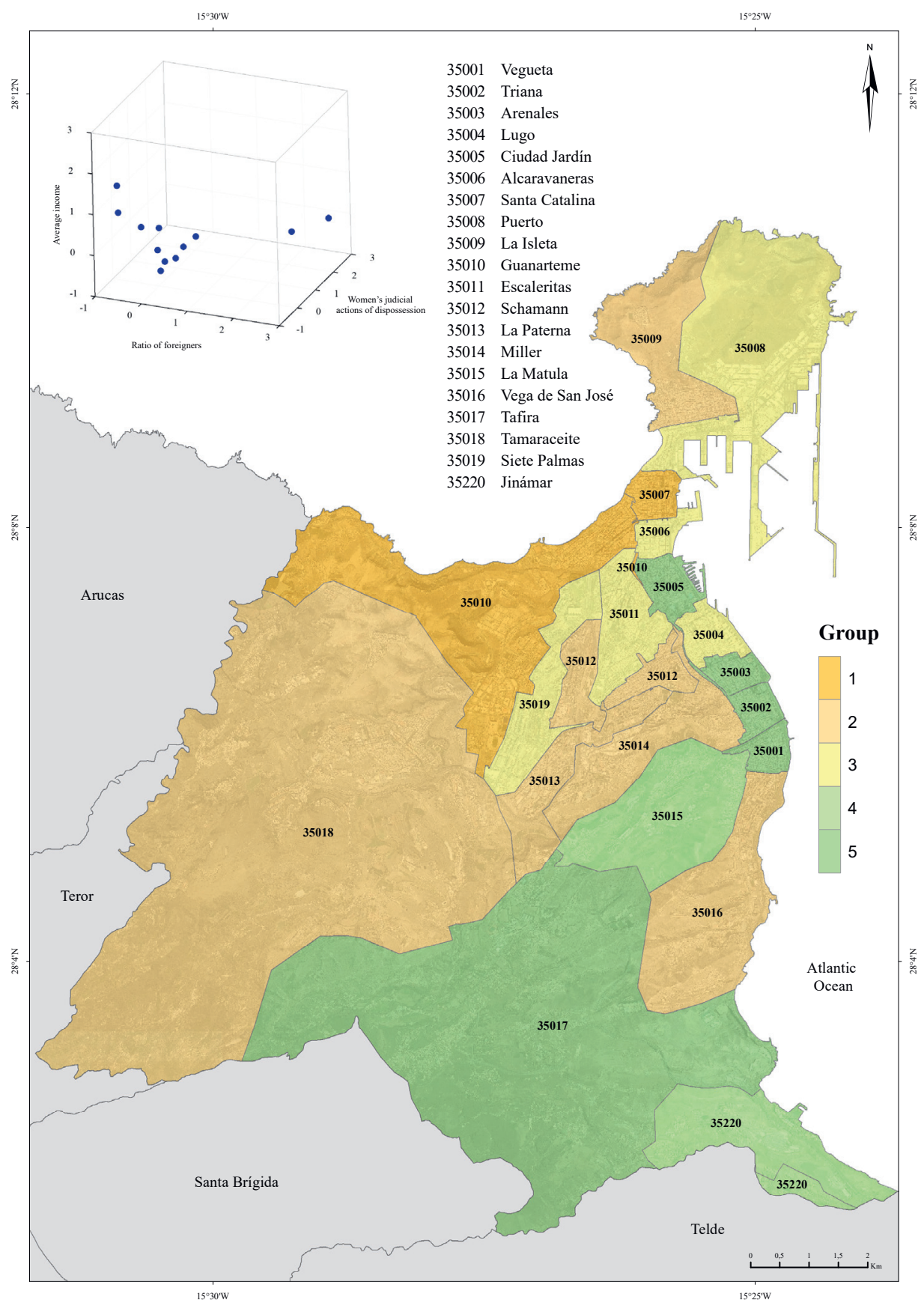

Fig. 5 - Map of urban areas according to women's foreclosures and evictions, income level and foreign ratio in Las Palmas de Gran Canaria. Source: Common Service of Notifications and Seizures, Tax Agency and Continuous Register of Population (INE). Elaborated by authors. 
Group 1 is made up of districts with the greatest number of legal actions carried out and the highest ratio of foreigners, especially non-European community foreigners. This is the port area and the degraded tourism district which is currently undergoing processes of gentrification. The other space with a significant presence of housing loss cases, Group 2, is made up of working-class neighbourhoods, with low income and an average presence of foreigners. This is a big zone of the city where low-quality and deteriorated housing in massive developments predominates, and recent lower-class real estate developments are being built. In sum, the first group is quite conditioned by foreign status and the second by income.

In the remainder of groups, the actions of housing loss involved lower values. Group 3 corresponds to spaces of middle-income and an average ratio of foreign population, including both the tourist areas of Las Canteras and the residential neighbourhoods of secondary centrality. Group 4, with few legal actions and foreigners, and with a low-income level, is an area of public housing and poor self-construction. Group 5 is like the previous group in relation to the number of foreigners and judicial proceedings, but with the highest income level in the city. It corresponds to central or peripheral spaces of garden city and downtown neighbourhoods.

Group 4 nuances the inverse relationship between income and loss of housing. This linkage is not always as clear, and the housing tenure structure is a complementary factor to be considered. In this regard, very poor female households that benefit from public renting or those in self-built houses are on the side-lines of foreclosures and evictions since they are outside the traditional capitalist circuits of access to housing. In summary, clustering allows us to appreciate that women living in low-income neighbourhoods and who do not benefit from the adjudication of public housing are especially affected. These seem to be foreigners in a remarkable proportion, and usually make up single-parent households.

\section{Conclusions}

As stated in several studies, a deep real estate crisis characterized by a high number of forced processes of housing privation started in Spain in 2008 with the beginning of the economic crisis and it has subsequently prolonged, reaching pre-pandemic times. Different factors can be argued to explain this long period of foreclosures and evictions: internal order factors such as traditional preference for housing ownership from dictatorial times; the level reached by the real estate business at the turn of the century; the financial bubble linked to subprime mortgage loans; and the legal corpus supporting the Spanish policy on financial institutions and the rental market. Other factors are, external order factors such 
as financialization of the global economy and the process of over-accumulation, leading to economic crisis; internationalization of the housing market; intervention of the so-called vulture funds in a context of capitalist repossession; and an increase in vacation rental accommodations, favouring processes of gentrification.

In this paper we have proposed to advance an interpretation of this loss of housing, focusing on gender as an explanatory factor and its intersection with income level and ethnicity. The empirical research developed is based on consultation of the judicial records of foreclosures and evictions carried out in the city of Las Palmas de Gran Canaria, differentiating people affected according to gender from an intraurban dimension. This allows us to confirm women's greater vulnerability in the housing market, especially when the category of gender intersects with social class and foreign status, as revealed by this geographical approach. In fact, the correlation between judicial actions against women, income level of households and foreign status of residents show the underlying factors that have caused housing deprivation, predominating among foreign and low-income women.

Specifically, women living in neighbourhoods with high- or medium-income levels and those with very low income are less affected. The first group is left out of the problem because the having a good income or do not suffer from job insecurity. The second because, due to their limited resources, they have solved their need for housing by obtaining public housing or through non-formal channels, such as selfbuilt housing. Consequently, it is women who lived in low-income neighbourhoods and those of foreign origin who especially suffered judicial loss of housing. The reason is threefold. First, because they are the ones who were able to benefit from the flexibilization of bank loans for purchase of houses and who later could not pay their debts. Second, because these low-income women had limited ability to pay their rent when the crisis worsened their work conditions. And third, because foreign women have tended to rent properties in some neighbourhoods where real estate revaluation, due to increase in vacation houses, has had a greater impact.

In consequence, the methodology used has revealed the power of geographical analysis to recognise social imbalances of housing deprivation in Spain, a country beaten harshly by the financial crisis and affected by new processes of tourist gentrification, especially in Mediterranean coastal areas and the two Spanish archipelagos. This makes clear what Valentine was already saying in 2007, that geography shows relationships between structural inequality and territorial models that favour certain groups and marginalise others (women-, middle- and low-income people and foreigners, in this case study).

Therefore, this research on the impact of property dispossession from a gender perspective can be considered a pioneering study in Europe. We have not found European empirical research beyond some qualitative studies, unlike what has happened in the USA, where it has a long tradition. Most of the research carried out in Europe is based on an analysis of the greater vulnerability of women in 
relation to the labour market and family responsibilities during times of crisis. Few scholars have approached the study of dispossession processes from a gender perspective. This category acquires full meaning when combined with those of class and ethnicity, as is revealed in the case study of Las Palmas de Gran Canaria, which opens the doors to similar research in the European context.

\section{References}

AALBERS, M.B. (2019): Financial geography II: Financial geographies of housing and real estate. Progress in Human Geography, 43, 2, 376-387.

ALEXANDRI, G., JANOSCHKA, M. (2018): Who loses and who wins in a housing crisis? Lessons from Spain and Greece for a nuanced understanding of dispossession. Housing Policy Debate, $28,1,117-134$.

ALLON, F. (2014): The feminisation of finance: gender, labour and the limits of inclusion. Australian Feminist Studies, 29, 79, 12-30.

ALMEIDA-GARCÍA, F., CORTÉS-MACÍAS, R., PARZYCH, K. (2021): Tourism Impacts, Tourism-Phobia and Gentrification in Historic Centers: The Cases of Málaga (Spain) and Gdansk (Poland). Sustainability, 13, 1, 408.

AMNESTY INTERNATIONAL (2017): La crisis de la vivienda no ha terminado. El derecho a la vivienda y el impacto de los desahucios de viviendas en alquiler sobre mujeres en España. Amnistía Internacional España, Madrid.

ANDREWS, D., CALDEA SÁNCHEZ, A. (2011): Drivers of homeownership rates in selected OECD countries. Economics Department Working Papers no. 849.

ANTHIAS, F. (2001): The material and the symbolic in theorizing social stratification: issues of gender, ethnicity and class. The British Journal of Sociology, 52, 3, 367-390.

ARREDONDO QUIJADA, R., PALMA GARCÍA, M. (2013): Aproximación a la realidad de los desahucios. Perfil y características de las familias en proceso de desahucios en la ciudad de Málaga. Alternativas, 20, 113-140.

BAYER, P., FERREIRA, F., ROSS, S. (2013): The vulnerability of minority homeowners in the housing boom and bust. Working Paper 19020. NBER Working Paper Series. http://www. nber.org/papers/w19020 (29.4.2020).

BESWICK, J., ALEXANDRI, G., BYRNE M., VIVES-MIRÓ, S., FIELDS, D., HODKINSON, S., JANOSCHKA, M. (2016): Speculating on London's housing future, City, 20, 2, 321-341.

BONDI, L., ROSE, D. (2003): Constructing gender, constructing the urban: a review of AngloAmerican feminist urban geography. Gender, Place and Culture, 10, 3, 229-245.

BOSCH MEDA, J. (2020): El derecho de la mujer a la vivienda en España (2008-2017). Revista Estudios Feministas 28, 1.

CASELLAS, A., SALA E. (2017): Home eviction, grassroots organisations and citizen empowerment in Spain. In Brickell, K., Arrigoitia M.F., Vasudevan, A. (eds.): Geographies of Forced Eviction. Dispossession, Violence, Resistance. Palgrave Macmillan, London, 167-190.

CASTRO BAKER, A. (2014): Eroding the Wealth of Women: Gender and the Subprime Foreclosure Crisis. Social Service Review, 88, 1, 59-91.

CHANT, S. (2013): Cities through a "gender lens": a golden "urban age" for women in the global South? Environment and Urbanization, 25, 1, 9-29. 
CONSTANTINE, M.G. (2002): The intersection of race, ethnicity, gender, and social class in counseling: Examining selves in cultural contexts. Journal of multicultural Counseling and Development, 30, 4, 210-215.

DESMOND, M. (2016): Evicted: Poverty and profit in the American city. Broadway books, Portland.

DESMOND, M. (2014): Poor black women are evicted at alarming rates, setting off a chain of hardship. Available at: https://www.macfound.org/media/files/HHM_Research_Brief_-_ Poor_Black_Women_Are_Evicted_at_Alarming_Rates.pdf (9.5.2020).

DESMOND, M. (2012): Eviction and the reproduction of urban poverty. American Journal of Sociology, 118, 1, 88-133.

DI FELICIANTONIO, C., AALBERS, M.B. (2018): The prehistories of neoliberal housing policies in Italy and Spain and their reification in times of crisis. Housing Policy Debate, 28, 1, 135-151. DOMÍNGUEZ-MUJICA, J. (2021): The Urban Mirror of the Socioeconomic Transformations in Spain. Urban Science, 5, 1, 13.

DOMÍNGUEZ-MUJICA, J., GONZÁLEZ-PÉREZ, J.M., PARREÑO-CASTELLANO, J.M., SÁNCHEZ-AGUILERA, D. (2021): Gentrification on the Move. New Dynamics in Spanish Mature Urban-Tourist Neighborhoods. Urban Science, 5, 1, 33.

DOMÍNGUEZ-MUJICA, J., PARREÑO-CASTELLANO, J.M., MORENO-MEDINA, C. (2020): Vacation rentals, tourism, and international migration: Gentrification in Las Palmas de Gran Canaria (Spain) from a diachronic perspective. In Handbook of research on the Impacts, challenges, and policy responses to overtourism IGI Global, 237-260.

DOMÍNGUEZ-MUJICA, J., PARREÑO-CASTELLANO, J., ARMENGOL-MARTÍN, M. (2020): Género y desposesión inmobiliaria en Las Palmas de Gran Canaria. In Farinós, J. et al. (ed.) Desafíos y oportunidades de un mundo en transición. Publicacions de la Universitat de València, Valencia, 637-646.

ETXEZARRETA ETXARRI, A., HOEKSTRA, J., DOL, K., CANO FUENTES, G. (2012): De la burbuja inmobiliaria a las ejecuciones hipotecarias. Ciudad y Territorio, 174, 597-613.

FABER, J.W. (2018): Segregation and the geography of creditworthiness: Racial inequality in a recovered mortgage market. Housing Policy Debate, 28, 2, 215-247.

FERREIRA, F., GYOURKO, J. (2015): A new look at the US foreclosure crisis: Panel data evidence of prime and subprime borrowers from 1997 to 2012 (No. w21261). National Bureau of Economic Research.

FOUCAULT, M. (2008): The Birth of Biopolitics 1978-1979. Palgrave Macmillan, New York.

GARCÍA-HERNÁNDEZ, J.S., GINÉS DE LA NUEZ, C. (2020): Geografías de la desposesión en la ciudad neoliberal: ejecuciones hipotecarias y vulnerabilidad social en Santa Cruz de Tenerife (Canarias-España). EURE, 46, 138.

GARCÍA-HERNÁNDEZ, J.S., DÍAZ-RODRÍGUEZ, M.C., GARCÍA-HERRERA, L.M. (2018): Auge y crisis inmobiliaria en Canarias: Desposesión de vivienda y resurgimiento inmobiliario. Investigaciones Geográficas, 69, 23-39.

GARCÍA-LAMARCA, M. (2016): (De)mortgaging Lives: Financialisation, Biopolitics and Political Subjectivation in the Barcelona Metropolitan Region. PhD Thesis, University of Manchester, UK. GUTIÉRREZ, A., ARAUZO-CAROD, J.M. (2018): Spatial Analysis of Clustering of Foreclosures in the Poorest-Quality Housing Urban Areas: Evidence from Catalan Cities. ISPRS International Journal of Geo-Information, 7, 1, 23.

GUTIÉRREZ, A., DOMÈNECH, A. (2020): Identifying the Socio-Spatial Logics of Foreclosed Housing Accumulated by Large Private Landlords in Post-Crisis Catalan Cities. International Journal of Geo-Information, 9, 5, 313. 
GUTIÉRREZ, A., VIVES-MIRÓ, S. (2018): Acumulación de viviendas por parte de los bancos a través de los desahucios: Geografía de la desposesión de vivienda en Cataluña. EURE, 44, 5-26. HEPBURN, P., LOUIS, R., DESMOND, M. (2020): Racial and Gender Disparities among Evicted Americans. Sociological Science, 7, 649-662.

HILL, A. (2011): Reimagining equality: Stories of gender, race and finding home. Beacon Press, Boston.

INE (2020): Continuous Register of Population. National Statistics Institute, https://www.ine.es/ dynt3/inebase/es/index.htm?type=pcaxis\&path=/t20/e245/p08/\&file=pcaxis\&dh=0\&capsel=1 (2. 4.2021).

INE (2017): Continuous Household Survey. National Statistics Institute, https://www.ine.es/ dynt3/inebase/index.htm?type=pcaxis\&path=/t20/p274/serie/prov/p01\&file=pcaxis\&L=1 (2. 4. 2021).

INE (2007): Life Conditions Survey. National Statistics Institute, https://www.ine.es/jaxi/Tabla. htm?path=/t25/p453/a2007/10/\&file=01001.px\&L=0 (2.4.2021).

JANOSCHKA, M., ALEXANDRI, G., OROZCO-RAMOS, H., VIVES.MIRÓ, S. (2019): Tracing the socio-spatial logics of transnational landlords' real estate investment: Blackstone in Madrid. European Urban and Regional Studies, 27, 2, 125-141.

LICHTENSTEIN, B., WEBER, J. (2015): Women foreclosed: a gender analysis of housing loss in the US Deep South. Social \& Cultural Geography, 16, 1, 1-21.

LOMBARDO, E. (2017): Austerity Politics and Feminist Struggles in Spain: Reconfiguring the Gender Regime? In Gender and the Economic Crisis in Europe. Palgrave Macmillan, Cham, 209-230.

MCCORMACK, K., MAZAR, I. (2015): Understanding Foreclosure Risk: The Role of Nativity and Gender. Critical Sociology, 41, 1, 115-132.

MENDES, L. (2018): Tourism gentrification in Lisbon. Neoliberal turn and financialisation or real state in a scenario of austerity urbanism. In I. David (ed.), Crisis, Austerity and Transformation: How Disciplining Neoliberalism in Changing Portugal. London: Lexington.

MÉNDEZ, R. (2017): De la Hipoteca al Desahucio: Ejecuciones Hipotecarias y Vulnerabilidad Territorial en España. Revista de Geografía Norte Grande, 67, 9-31.

MIRAFTAB, F. (2001): Risks and opportunities in gender gaps to access shelter: a platform for intervention. International Journal of Politics, Culture and Society, 15, 1, 143-160.

PARREÑo-CASTELLANO, J., DOMÍNGUEZ-MUJiCA, J., ARMENGOL-MARTÍN, M., BOLDÚ-HERNÁNDEZ, J. PÉREZ-GARCÍA, T. (2019): Real estate dispossession and evictions in Spain: a theoretical geographical approach. Boletín de la Asociación Española de Geografía, 80, 1-25.

PARREÑo-CASTELLANO, J., DOMÍNGUEZ-MUJICA, J., ARMENGOL-MARTÍN, M., BOLDÚ-HERNÁNDEZ, J. PÉREZ-GARCÍA, T. (2018): Foreclosures and Evictions in Las Palmas de Gran Canaria during the Economic Crisis and Post-Crisis Period in Spain. Urban Science, 2, 4, 109.

PARREÑO-CASTELLANO, J. M., DOMÍNGUEZ-MUJICA, J., MORENO-MEDINA, C. (2020): Real estate dispossession, income and immigration in Las Palmas de Gran Canaria (Spain). Boletín de la Asociación Española de Geografía, 87.

RAYA, J.M. (2018): The determinants of foreclosures: Evidence from the Spanish case. Papers in Regional Science, 97, 4, 957-970.

ROBERTS, A. (2013): Financing social reproduction: The gendered relations of debt and mortgage finance in twenty-first-century America. New Political Economy, 18, 1, 21-42. 
SABATER FERNÁNDEZ, C., GIRÓ MIRANDA, J. (2016): New poverty. Eviction as a process of exclusion. Ehquidad. International Welfare Policies and Social Work, 3, 77-106.

SÁNCHEZ, M.I. (2015): Sinhogarismo de las familias monomarentales. En Actas del V Congreso universitario internacional investigación y género. Universidad de Sevilla, Sevilla, 214-225.

SUÁREZ, M. (2017): The subprime middle class: precarious labour, mortgage default, and activism among Ecuadorian migrants in Barcelona. PhD Thesis, University of London, London.

TREASURY (2019): Estadística de los declarantes del Impuesto sobre la Renta de las Personas Físicas de los mayores municipios por código postal, https://www.agenciatributaria.es/AEAT. internet/datosabiertos/catalogo/hacienda/Estadistica_del_IRPF_por_codigo_postal.shtml (9. 5. 2020).

VALENTINE, G. (2007): Theorizing and researching intersectionality: A challenge for feminist geography. The Professional Geographer, 59, 10-21.

VASQUEZ-VERA, H., RODRÍGUEZ-SANZ, M., PALENCIA, L., BORRELL, C. (2016): Foreclosure and health in southern Europe: results from the platform for people affected by mortgages. J. Urban Health 93, 312-330.

VIVES-MIRÓ, S., RULLAN, O., GONZÁLEZ-PÉREZ, J. (2018): Cartografías de los desplazamientos por desposesión de vivienda. Desahucios y ejecuciones hipotecarias en Palma a través de su geohistoria. Scripta Nova, XXI, 591.

WÖHL, S. (2017): The gender dynamics of financialization and austerity in the European Union The Irish case. In Gender and the Economic Crisis in Europe. Palgrave Macmillan, Cham, 139-159.

WYLY, E., PONDER, C.S. (2011): Gender, age, and race in subprime America. Housing Policy Debate, 21, 4, 529-564.

\section{ACKNOWLEDGEMENTS}

We would like to express our gratitude to the Common Service of Notifications and Seizures of the Las Palmas de Gran Canaria Judicial District and to its Judicial Secretary, for the support given. This research was funded by the Spanish Ministry of Science, Innovation and Universities; State Research Agency (AEI) and the European Regional Development Fund (ERDF) with the R\&D project "Housing and international mobility in cities of the Canary Islands. The emergence of new forms of urban inequality" (RTI2018-093296-B-C21).

\section{ORCID}

JOSEFINA DOMÍNGUEZ-MUJICA

https://orcid.org/0000-0001-7460-5553

JUAN PARREÑO-CASTELLANO

https://orcid.org/0000-0002-1082-456X 